\title{
HOSPITALITY OF THE PEOPLES OF THE NORTH CAUCASUS AS ONE OF THE ELEMENT OF ETHNIC CULTURE
}

\author{
(C) Alina A. Ostapuschenko, Yulia A. Petrova \\ Rostov State University of Economics (RSUE), Rostov-on-Don, Russian Federation \\ science-almanac@mail.ru
}

The most important public institution of the North Caucasus peoples, hospitality, is being explored. Its centuries-old history, features, character and functions are analyzed. Nowadays with the development of telecommunication links, of the world-wide Internet, the studied social institution loses its importance and undergoes many changes. At the same time, some of its elements continue to be passed on from generation to generation. Thanks to this continuity, the peoples of the North Caucasus manage to preserve their identity and uniqueness and not to lose sight of the social and cultural phenomenon of globalization. Multiculturalism of the peoples of the North Caucasus implies close cultural ties, linguistic and behavioral competences. The study of the experience of hospitality allows not only to confirm its importance in strengthening and uniting people, but also to contribute to the rise of the unique social organization and of the interactivity of the cultural environment. Hospitality activates the creative potential of the individual in carrying joy to people.

Key words: hospitality, the North Caucasus, Highlanders, institute of hospitality, customs, traditions, reverence of the guests.

\section{[А.А. Остапущенко, Ю.А. Петрова Гостеприимство народов северного Кавказа как один из эле- ментов этнической культуры]}

Исследуется важнейший общественный институт северокавказских народов - гостеприимство. Анализируется его многовековая история, особенности, характер, фуункции. В современном мире с развитием телекоммуникационных связей, всемирной сети Интернет, изучаемый социальный институт утрачивает былую значимость и претерпевает множество изменений. Вместе с тем некоторые его элементы продолжают передаваться из поколения в поколение. Благодаря данной преемственности, народам Северного Кавказа удается сохранять свою самобытность и уникальность и не померкнуть в социокультурном френомене глобализации. Многокультурность народов Северного Кавказа предполагает наличие тесных культурных связей, лингвистических и поведенческих компетенций. Изучение опыта гостеприимства позволяет не только подтвердить его значимость в укреплении и сплочении людей, но и способствовать расцвету уникальной социальной организации, интерактивности культурной среды. Гостеприимство активизирует творческий потенциал личности в том, чтобы нести радость людям.

Ключевые слова: гостеприимство, Северный Кавказ, горцы, институт гостеприимства, обычаи, традиции, почитание гостя.

Alina A. Ostapuschenko - second-year student, Rostov State University of Economics (RSUE), Rostov-on-Don, Russian Federation.

Yulia A. Petrova - Ph.D. in Philosophy, Associate Professor, Rostov State University of Economics (RSUE), Rostov-on-Don, Russian Federation.

Остапущенко Алина Александровна - студентка второго курса, Ростовский государственный экономический университет (РИНХ), г. Ростов-на-Дону, Российская Федерация.

Петрова Юлия Андреевна - кандидат философрских наук, доцент, Ростовский государственный экономический университет (РИНХ), е. Ростов-на-Дону, Российская Федерация.

The North Caucasus has been considered a unique region for a long time. There are numerous ethnic groups living here in a comparative-small territory, having their own culture, 
the most important components of which are customs and traditions which are passed on from generation to generation.

Folk traditions and customs are a mirror, an appearance of the people. Studying traditions and customs of the peoples of the Caucasus, it is possible to trace their centuries-old history.

In shaping the mentality of the North Caucasus peoples, traditional social institutions such as riding, class-representative assembly (khasa), hospitality, consecrated friendship, patronage, brotherhood, abrechestvo (people's guerrilla movement in the Caucasus), blood revenge, adoption, etc., played a major role. All these traditional institutions were in close dialectical interrelation. With their help, relations between people, classes and ethnos were regulated.

Hospitality is the most ancient public institution in the mountains of the Caucasus supported by many foreign and domestic travelers and scientists, as well as our contemporaries: J. Bell, L.J. Lulje, F.F. Thornau, I.L. Babich, N.V. Volkova, V.K. Gardanov and others [1].

Hospitality embodied diplomatic, economic and sociocultural relations between people of different nationalities, characterized by special nobility, loyalty, dedication, readiness to go through thick and thin [3]. Numerous migrations over the centuries had made the ethnic map of the region one of the most underexplored in the world. It was the custom of special reverence of the guests. It originated hundreds of years ago and therefore has a solid historical basis. Hospitality was a consequence of the heavy mountain way of life, when the man constantly needed to overcome harsh natural conditions and to defend himself from enemies persistently. In the mountains it was natural to rely on the help of relatives and neighbors. In addition, with the help of skilled hospitality, intensive social relations were established and trade contacts were maintained not only among countrymen, but also between representatives of different nationalities. Guests are also tenacious patrons, commercial partners and possibly future relatives. In the Caucasus stories are known when new families were created with the participation of the guest and fates were successfully formed [6].

One of the features of mountain hospitality is its sacral character. Each host accepts every wanderer with sincere greetings, provides him with all kinds of services, gives him money if he needs it, and he stakes his life on him while he is considered his guest and he is under the same roof with him. Therefore, in the folklore of the Adygeis, the Chechen, the Ingush, the Nogayans there are proverbs that mean the same thing: "Guest is the messenger of God". On the contrary, the inhospitable family was spoken about: "Whose house is poor by guests, that house is cursed".

According to the researcher Lapinsky, the best quality of the Adygeis is a hospitality. The traveler can drive through the whole country without a penny of money, and he will be detained nowhere, and in every yard where he will go, he will find a shelter, a bed and food for himself, a stable and fodder for his horse. It is possible, without asking permission, to get off the horse in front of the saklia for guests and enter it. It is such a custom. Now mattresses, pillows, water and towel are brought from the yard, a large fire is lit in the fireplace, and the host and his family serve the guest... No wealthy traveler can be better served in a European hotel than a guest in a low Adighe saklia under a straw roof.

It should be noted that hospitality in the Caucasus implies the presence in the house of each mountain family of a special guest room or even a separate guest house called "kunatskaya". The Institute of kunatskaya was known to all peoples of the Caucasus. The doors of the kunatskaya were always open, and in the princely houses of Cirkassia "in case of guests" in the kunatskaya there was always a set table, food on which was changed three times a day. The kunatskaya was both a restaurant and a concert hall, and a cabinet where political problems were solved, and a university for the younger generation [1]. 
In the Caucasus it is not common to stay in a house where there were no men, although having a separate guest house the mistress offered to stay out of courtesy.

In the kunatskaya the guest took a place of honor, the host sat with guests either after long invitations or did not sit at all. The elders sat, the youngest stood and served everybody. The women were not accepted to participate in the reception, but the mistress could come in and greet the guest.

At the end of the 18th century in the travel notes the academician Peter Simon Pallas drew attention to the strict duties of receiving a guest of the peoples of the North Caucasus: "Two opposite laws, hospitality and blood revenge, are observed scrupulously by both Circassian nobility and most other peoples of the Caucasus" [7, 221 p.]. The mountain hospitality admired all the travelers by the fact that no matter how hard it was for the host, he received guests kindly. The Highlanders used the tradition of hospitality in connection with joyful events, big holidays, business trips. In hospitality, together with the inherent duty of this tradition, the defining place was occupied by the sense of tact, the calculation of the possibilities of a particular host, his family status and financial situation.

Despite the fact that all North Caucasus peoples without exception possessed this imperative, the hospitality of each ethnic group had its own distinctive features. It consisted mainly in a solemn reception of the guest, that was difficult for the Highlanders, especially materially. This reception was distinguished in many ways for two types of guests, guests of honor and dear guests. Guests who arrived from afar were considered guests of honor. Dear guests were relatives, especially blood, as well as people living relatively close or often visiting the house. There were also different traditions of reception of guests. Of course, the reception ceremony of guests of honor was more solemn, while the ritual of receiving dear guests was simpler and more modest. Men and women were also received differently.

The visiting guest should not have been asked about his origin and the purpose of the visit. It was considered as bad manners. According to the custom of the Ossetians, the guest had the right to keep his incognito even for the whole month, the rest of the North Caucasus peoples had a certain limit of time: the Adygeis and the Balkars had three days, the Abazins had a week, the Ingush and the Chechen had 20 days [4].

After the foreigner crossed the threshold of the kunatskaya and became a guest of this house, it was not accepted to move to another dwelling. Such act insulted the master and was condemned in the people. The guest could leave the house of his hosts only in the case, when it seemed that he was not very welcome in this family. Early in the morning he left the kunatskaya without saying goodbye. Behind the abandoned family the nickname "the family chased the guest away" was fixed for long generations. Therefore, the Highlanders made all the efforts to please the visitor.

The guest left all his weapons at the doors of the kunatskaya, except for the dagger, thus, on the one hand, fully trusting his life to the host, and on the other hand, demonstrating that his visit does not threaten the safety of his hosts.

The host is responsible to the whole people for the safety of foreigners, and who failed to save the guest from trouble, or even from simple trouble, that was judged and punished. The host had to sacrifice his life for the guest, if it was necessary.

Hospitality of the Highlanders in importance overlapped all other social institutions (even blood revenge). The example is M. Lakerbay's story "Guest". The old Abkhazian Hanasha Chugba was sewing soft leather shoes for his only son Temyr. Suddenly, a breathless young Circassian ran into the yard and begged him to hide him from the chasers. The old man hid the guest in the attic without thinking. Convinced that there was no chase, he gave food and water to the frightened young man and asked: "Who is chasing you and why?" The young man replied that he killed an unfamiliar guy who had insulted him and whipped his horse. Now the dead man's friends want to kill him. At this time, the crowd of people approached the 
house, carrying a heavy burden wrapped in a burka. The old white-haired man came out of the crowd and said: "Stay strong, Hanasha! You have a great grief... Today, your Temyr was killed by an unknown Circassian!" The old man`s legs trembled, he was picked up by the friends. Two days the women mourned young Temyr. For two days, under various excuses, the old man went up to the attic to bring food to the guest. On the third day, he called the Circassian: "Go, my guest! There's no one here. Go through the forest, it is closer to the crossing. The night is dark, no one will see you" [1].

The custom of hospitality is clearly reflected in the folklore of the Highlanders. One Vainach legend describes how the brothers caught and brought home their long-time archenemy. When the circumstances forced them to leave, their mother took pity on the prisoner, who asked for water and food, and gave him food. When the brothers returned home, they learned what had happened, and they had to let the enemy go because they could not punish the man who ate and drank in their house. They decided to take revenge on the enemy sometime later when he was caught again.

Official visitors to the possessions of such hereditary rulers such as shamkhal Tarkovsky on the coast of eastern Dagestan, the avar khan in the mountainous West and Sultan Ilisu in the northern part of modern Azerbaijan, were often struck by hospitality and greatness with which they were received. Jacques-François Gamba, a French consul from Tiflis, talked about one evening spent with a shamchal from Tarka in the early 1820s: "They carried in front of us four huge dishes loaded with white bread and cakes of different varieties, rice pilaff, portions of which were extraordinary sizes. Sorbets and beautiful fruits completely covered the dishes. The same night, they killed a few sheep and two bull-calves. They generously and selflessly supplied our caravan with all necessary products and provisions" [10].

The custom of hospitality is also described in the work of Julius von Klaprot, describing his journey through the Caucasus and Georgia, undertaken in 1807-1808. The author's conclusions confirmed many ideas which could help to form the social opinion about the Caucasus throughout the 19th century Klaprot reinforced the view that the Caucasian peoples were wildly wasteful in their hospitality. But at the same time, they are cruel to those who did not fall into the category of protected guests. The Ingush, for example, represented typical Caucasian mix distinguished and retrograde: "In observance of the rights of hospitality, in possession of their general property, in fair division of the fact that the destiny or accident throws on their way they lose visibility of wild life and seem movable more humane feelings, than we do, predatory Europeans who consider themselves distinguished and civilized..." [13].

Hospitality has its own elements, one of which is a generous feast which plays an important role. It is believed that the reception of guests shows the level of well-being of the family. The desire to appear before guests in the best light, to show their skill in reception led to the development of the art of cooking, when in conditions of lack of products, the hosts tried to serve as many different dishes on the table as possible. Now the Caucasus cuisine is famous for this. This contributed to the creation of a traditional culture of feast (traditional toast-master, musicians, feast songs).

For the Highlanders, on the one hand, hospitality was valued as a form of communication. Thus, they were interested in the guest, who came from afar, as in a carrier of valuable information, so the Highlanders met foreign travelers with special honor. On the other hand, the element of ethno-cultural continuity was seen as a form of leisure, so that guests who came just to visit were seen above "business". Thus, in general, the custom of hospitality was the most important norm of life in the traditional household of the peoples of the Caucasus. It had been considered higher in its importance than other social institutions and the need to implement it had sidelined the obligation to follow other standards of conduct.

In the 20th century hospitality as a social institution began to fade gradually. The development of telecommunication links, especially of the worldwide Internet, has made it possible 
to maintain communication at anytime and anywhere in the world. As a result, the informative and trading functions of the guests gradually began to erode. But, nevertheless, hospitality is preserved as a custom, a tradition, a norm of ethics, and today's Caucasian is not less welcoming than his previous generation of relatives.

It should be noted that hospitality as an element of ethno-cultural continuity, having a centuries-old history, performed various functions. First of all, integrating and informational; communicational and regulating relations within and between different ethnic groups; legal and socio-controlling. Owing to changes in the structure of social relations, some functions has changed their scope, but has not lost their importance in modern life. Thus, reverence of the guest in the presentation of contemporaries has changed: today people do not bow so much in front of an unfamiliar guest, even a foreigner. As an addition, the following characteristics should be present: special merits in sports, culture, education, official status and authority in society. The privilege of "seniority" remained unchanged, the biological age plays an important role. Guests-relatives and guests-friends remain in honor. The reverence of longdistance guests at a wedding or other events has also been preserved. In relation to strangers, hospitality is declarative in nature. Such form of reception of guests as etiquette has been slightly simplified, although some of its features have still survived until today: the host side welcoming the guest was standing, and sat down after he had sat, the guest does not stay without a treat, all family members escort him. However, it should be noted that young people in cities no longer always adhere to etiquette [2].

Without a doubt, the hospitality of the peoples of the Caucasus had deep historical roots. To this day, it is not only the most sustainable tradition, but also a life installation that passes on from generation to generation. This layer of mentality is more conservative and in its main functions is woven into the system of modern values.

In 2017, the School of Caucasus Hospitality was opened on the basis of the Institute of Service, Tourism and Design (North Caucasus Federal University, Pyatigorsk). The North Caucasus, which is the international pearl of tourism in Russia, needs specialists with practical skills consistent with the European standard of service and hospitality [8].

The strategy of socio-economic development of the North Caucasus assumes that at least 100,000 new jobs should be created by 2025, and North Caucasus Federal University, as the largest university in the region, has already started the process of training highly qualified personnel [8].

Thus, the oldest customs and traditions of hospitality of the peoples of the North Caucasus do not die, but also find their expression in a new and modern format. The purpose of the new social organizations and institutions is not to destroy the feelings and joy of life, but to promote their heyday, within the limits not detrimental to others. Schools of Caucasus hospitality are a form of reproduction of cultural norms, values, traditions and ideas, which is directly related to hospitality, to the need to create in the structure of social relations cultivation of traditions, rites, customs, development of positive experience of life creation of people in society.

\section{Лumepamypa}

1. Ашхамахова A. А. Гостеприимство, как определяющая менталитета народов Северного Кавказа // Современное право. 2006. № 12.

2. Баласултанова А.Э. Гостеприимство как один из элементов этнической культуры народов Кавказа // Мир науки. Социология, фрилология, культурология, 2016. № 1. https://sfk-mn.ru/PDF/09SFK116.pdf (дата обращения: 18.09.19).

3. Блейх Н. О. Институт гостеприимства - важнейший этикетный императив северокавказских народов // Локус: люди, общество, культуры, смыслы. Культура. Культу- 
рология, 2016. https://cyberleninka.ru/article/n/institut-gostepriimstva-vazhneyshiyetiketnyy-imperativ-severokavkazskih-narodov (дата обращения: 20.09.19).

4. Блейх Н.О. Историческая динамика трансформации северокавказского обычая гостеприимства // Вопросы культурологии. 2014. № 8.

5. Лапинский T. Горцы Кавказа и их освободительная борьба против русских. Описание очевидца Теофила Лапинского (Теффик-бея) полковника и командира польского отряда в стране независимых горцев. Нальчик. Эль-Фа. 1995.

6. Нефляшева Н. Северный Кавказ сквозь столетия // Кавказский узел. 2012. https://www.kavkaz-uzel.eu/blogs/1927/posts/11014 (дата обращения: 20.09.19).

7. Паллас П. Заметки о путешествиях в южные наместничества Российского государства в 1793 и 1794 годах. М., 1999.

8. Петрова Ю.А. Многокультурность и межкультурность, культура и язык в XXI веке. // Гуманитарные и социальные науки. 2019. № 4.

9. Школа Кавказского гостеприимства СКФУ // http://pf.ncfu.ru/department/f3/shkolakavkazskogo-gostepriimstva-skfu/ (дата обращения: 05.10.19).

10. Gamba J.F. Voyage dans la Russie, издательство: Оникс, 2012. C. 350-351.

11. Chernous V. The Genesis of Caucasian Mountain Civilization // Научный альманах стран Причерноморья. 2019. № 2. URL: http://science-almanac.ru

12. King Ch., The Ghost of Freedom: A History of the Caucasus, Tantor Audio; Unabridged edition, 2008. $-314 \mathrm{p}$.

13. Klaproth von J. Travels in the Caucasus and Georgia. 1814. $421 \mathrm{p}$.

14. Kolosova O., Goncharov V. Ethnic functions of culture: social and philosophical analysis of ethnographic research // Научный альманах стран Причерноморья. 2018. № 3. URL: http://science-almanac.ru/documents/211/2018-03-03-Goncharov.pdf

15. Petrova Y.A. Ethnography of communication // Гуманитарные и социально экономические науки, 2016. № 2.90 с.

16. Petrova Y.A., Lebesheva A.A., Kamalov A.V. Development of tourism in the Crimea as an economic problem of the region // Научный альманах стран Причерноморья. 2018. № 4 (16), c. 37-41 URL: http://science-almanac.ru

\section{References}

1. Ashkhamakhova A. A. Gostepriimstvo, kak opredeliaiushchaia mentaliteta narodov Severnogo Kavkaza. [Hospitality as the defining mentality of the peoples of the North Caucasus]. Modern law. 2006. No. 12.

2. Balasultanova A.E. Gostepriimstvo kak odin iz elementov etnicheskoi kultury narodov Kavkaza. [Hospitality as one of the elements of the ethnic culture of the peoples of the Caucasus]. World of Science. Sociology, Philology, Cultural Studies, 2016. No. 1. Available at: https://sfk-mn.ru/PDF/09SFK116.pdf (accessed 18 September 2019).

3. Bleikh N. O. Institut gostepriimstva - vazhneishii etiketnyi imperativ severo-kavkazskikh narodov. [Institute of hospitality is the most important label imperative of the North Caucasus peoples]. Locus: people, society, cultures, meanings. Culture. Culturology, 2016. Available at: https://cyberleninka.ru/article/n/institut-gostepriimstva-vazhneyshiyetiketnyy-imperativ-severokavkazskih-narodov (accessed 20 September 2019).

4. Bleikh N.O. Istoricheskaia dinamika transformatsii severokavkazskogo obychaia gostepriimstva. [Historical Dynamics of Transformation of the North Caucasus Custom of hospitality]. Issues of Cultural Studies. 2014. No. 8. 
5. Lapinsky T. Gortsy Kavkaza i ikh osvoboditelnaia borba protiv russkikh. Opisanie ochevidtsa Teofila Lapinskogo (Teffikbeia) polkovnika i komandira polskogo otriada $v$ strane nezavisimykh gortsev. [The Highlanders of the Caucasus and their liberation struggle against the Russians. Description of the witness Theophile Lapinsky (Teffikbey) colonel and commander of the Polish detachment in the country of independent Highlanders]. Nalchik. El-Fa. 1995.

6. Neflyasheva N. Severnyi Kavkaz skvoz stoletiia. [The North Caucasus through centuries]. Caucasus node. 2012. Available at: https://www.kavkazuzel.eu/blogs/1927/posts/11014 (accessed 20 September 2019).

7. Pallas $P$. Zametki o puteshestviiakh $v$ iuzhnye namestnichestva Rossiiskogo gosudarstva v 1793 i 1794 godakh. [Travel Notes to the Southern Provinces of the Russian State in 1793 and 1794]. Moscow, 1999.

8. Petrova Y.A. Mnogokulturnost i mezhkul'turnost, kultura i iazyk v KhKhl veke. [Multiculturalism and interculturality, culture and language in the 21st century]. Humanities and social sciences. 2019. No. 4.

9. Shkola Kavkazskogo gostepriimstva SKFU. [School of Caucasus Hospitality North Caucasus Federal University]. Available at: http://pf.ncfu.ru/department/f3/shkolakavkazskogo-gostepriimstva-skfu/ (accessed 05 October 2019).

10. Gamba J.F. Voyage dans la Russie, publishing house: Onyx, 2012. pp. 350-351.

11. Chernous V. The Genesis of Caucasian Mountain Civilization. Science almanac of Black Sea region countries. 2019. No. 2. Available at: http://science-almanac.ru

12. King Ch., The Ghost of Freedom: A History of the Caucasus, Tantor Audio; Unabridged edition, 2008. 314 p.

13. Klaproth von J. Travels in the Caucasus and Georgia. 1814. 421 p.

14. Kolosova O., Goncharov V. Ethnic functions of culture: social and philosophical analysis of ethnographic research. Science almanac of Black Sea region countries. 2018. No. 3. Available at: http://science-almanac.ru/documents/211/2018-03-03-Goncharov.pdf

15. Petrova Y.A. Ethnography of communication, Humanities and socio-economic sciences, 2016. No. 2. 90 p.

16. Petrova Y.A., Lebesheva A. A., Kamalov A. V. Development of tourism in the Crimea as an economic problem of the region. Science almanac of Black Sea region countries. 2018. No. 4 (16), pp. 37-41. Available at: http://science-almanac.ru

4 November, 2019 